\title{
Studies of the ringed seal (Phoca hispida Schreber 1775) in its breeding habitat in Kongsfjorden, Svalbard
}

\author{
CHRISTIAN LYDERSEN AND IAN GJERTZ
}

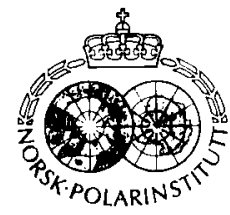

\begin{abstract}
Lydersen, C. \& Gjertz, I. 1986: Studies of the ringed seal (Phoca hispida Schreber 1775) in its breeding habitat in Kongsfjorden, Svalbard. Polar Research 4 n.s., 57-63.

This study was conducted in Kongsfjorden, Svalbard, from mid-March through April 1984. Local Greenland sled dogs were used to locate subnivean ringed seal lairs. A total of 90 lairs were found and excavated. These constituted 28 lairs classified as birth lairs, 22 as tiggak (rutting male) lairs, and 40 which could not be classified. The first birth lair was found on 24 March. There was significantly more snow covering birth lairs than tiggak lairs, and birth lairs were also shown to be significantly larger than tiggak lairs. The positions of the lairs were plotted on a map, and distances between neighbouring seal lairs were used as an indicator of territorial size. Arctic foxes had attacked 19 lairs and 6 of these had resulted in a kill (32\%). Polar bears had attacked 13 lairs with one kill $(8 \%)$.
\end{abstract}

Christian Lydersen and lan Gjertz, Norsk Polarinstitutt, P.O. Box 158, 1330 Oslo Lufthavn, Norway; November 1985 (revised January 1986).

The ringed seal (Phoca hispida) is probably the most abundant seal in the Arctic Ocean and adjacent waters (Stirling \& Calvert 1979). Ringed seals associate closely with land-fast ice or heavy pack ice where they maintain breathing holes with the aid of the foreflippers. When sufficient snow accumulates the seals may dig haul-out lairs in the snow covering the breathing holes (Smith \& Stirling 1975). These lairs offer protection from predators and cold. In late March and April females give birth to a single pup, which is usually born in a lair, appropriately called the birth lair (Fig. 1). Birth lairs may be recognized by the presence of placental remains, moulted hairs from the white-coat (lanugo) and by the pup's charac-

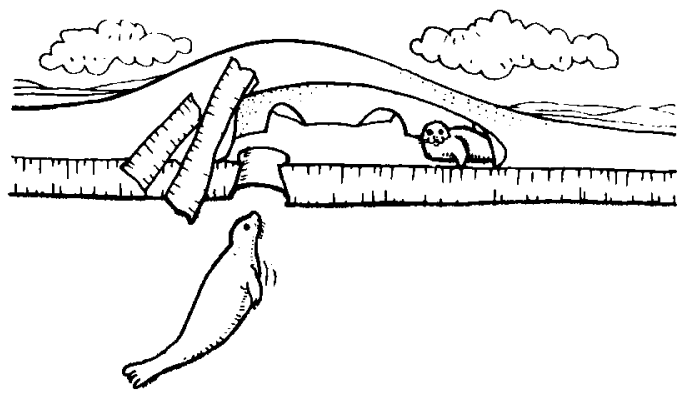

Fig. I. Cross section of a birth lair (from Gjertz \& Lydersen 1983). teristic tunnelling in the lair (Smith \& Hammill 1981). Placental remains are quickly removed, however, so the odour will not attract predators (Stirling 1977). Other specialized haul-out lairs have also been recognized. Smith \& Stirling (1975) mention suckling-, learning- and escapelairs for pups and, in addition, rutting male lairs and communal lairs used by several seals.

Ringed seals are the most important food for the polar bear (Ursus maritimus) in Svalbard (Lønø 1970). Polar bears hunt ringed seals most successfully in areas of moving pack ice and along the edge of the fast ice or floe edge (Stirling 1974; Stirling \& Latour 1978). The prime breeding habitat of ringed seals located in ice hummock areas is less subject to predation by bears than other ice types (Smith 1980). The complexity of the birth lairs and possible olfactory confusion may account for this. Arctic foxes (Alopex lagopus) which enter the birth lairs and kill pups are also important predators. Smith (1976) estimated that arctic foxes are capable of killing up to $26.1 \%$ of ringed seal pups in nearshore sea ice.

The main objectives of this study were to investigate the distribution, abundance and structures of subnivean lairs in a western Spitsbergen fjord, and to try to establish the extent of polar bear and arctic fox predation on ringed seals in a fjord ice area. 


\section{Material and methods}

Kongsfjorden (Fig. 2) was chosen as the study area because $\mathrm{Ny}$ - $\AA$ lesund, with its scientific base, offers excellent facilities for high Arctic research. Kongsfjorden is known as a breeding area for ringed seals and a previous study of ringed seal lairs had been conducted there by Taugbøl (1982).

The present study was conducted from midMarch to the end of April 1984. In mid-March Kongsfjorden was covered by winter ice with areas of pressure ridges and glacier ice favourable for seal lairs (Fig. 3). The snow cover varied during the study period with precipitation and wind, but was on average about $15 \mathrm{~cm}$ on even fjord ice. The Kongsfjorden ice cover changed during the study period when large areas of the fast ice broke up and drifted to sea (Fig. 4). This happened mainly when waves from the west were followed by strong easterly winds.

The fjord ice was systematically searched for lairs. For practical reasons the search started in the northern parts of the fjord. The southeastern part, which contained areas well suited for seal lairs. could not be completely searched because of the disappearance of large parts of the fjord ice. Dogs were used to locate the lairs, and probes were also used to search snowdrifts for possible lairs. Lairs newly opened by predators were readily discovered even though the dogs often disregarded them. In strong winds the search was

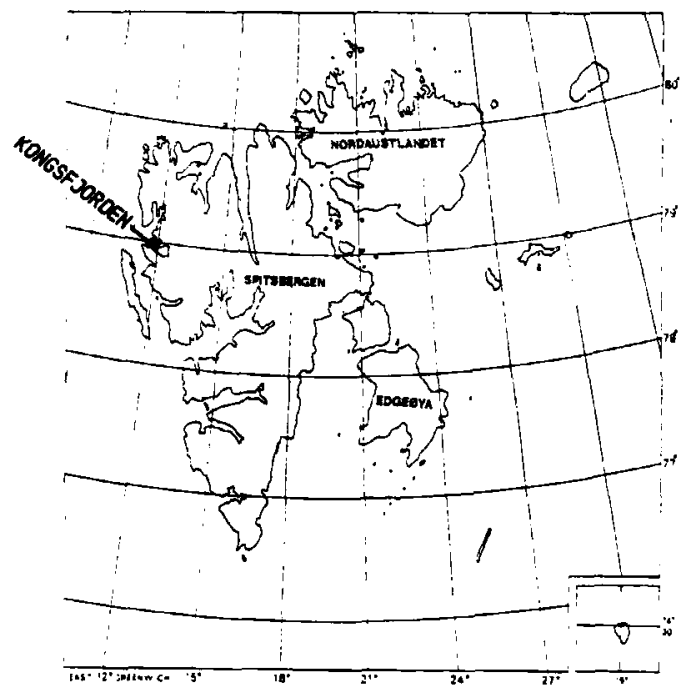

Fig. 2. Map of Svalbard showing the location of Kongstjorden.

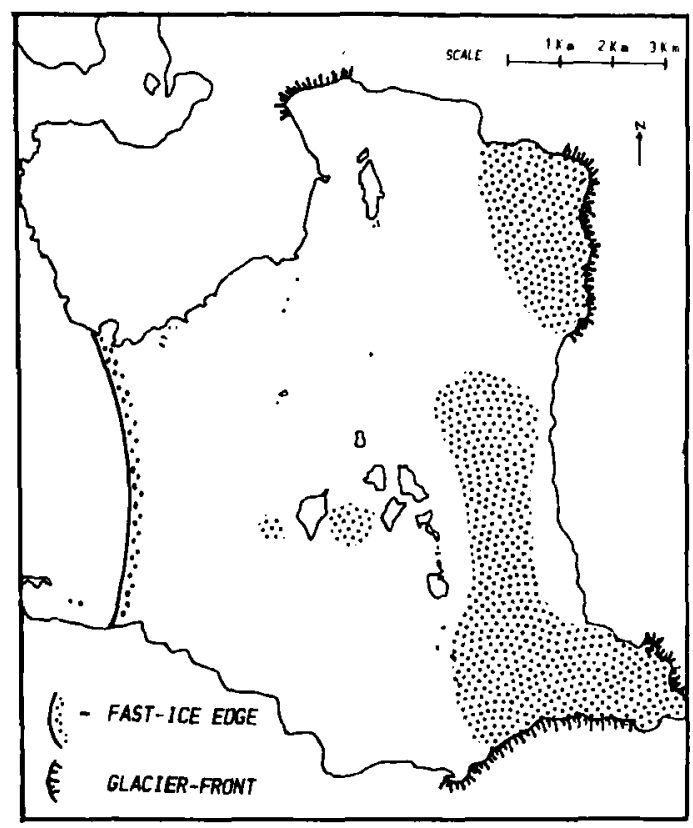

Fig. 3. Map of the ice cover in Kongsfjorden on 15 March. Arcas where snow-and ice-conditions are favourable for ringed seal lairs are hatched.

called off because the wind prevented the dogs from making a thorough search for lairs. Trained dogs could not be brought from the Norwegian mainland for this study due to the strict rabies quarantine regulations which apply between Svalbard and the rest of Norway. Local Greenland sled dogs were therefore used.

When a dog got the scent of a lair it would try to pounce on the roof of the lair in order to break through. If it did not succeed the dog would dig until the lair was reached. The dogs would also pounce on snow covered breathing holes, but as this study was concerned with lairs only, breathing holes were disregarded.

Once located, each lair was excavated and classified by the following critera:

1. Birth lair - lair containing evidence of a birth or with tunnels dug by the pup.

2. Tiggak lair - haul out lair with the characteristic smell of a rutting male.

2. Indet. lair - lairs not classified as 1 or 2.

The following measurements were taken: maximum height inside the lair, snow depth covering the lair and the lair's linear dimensions. The 


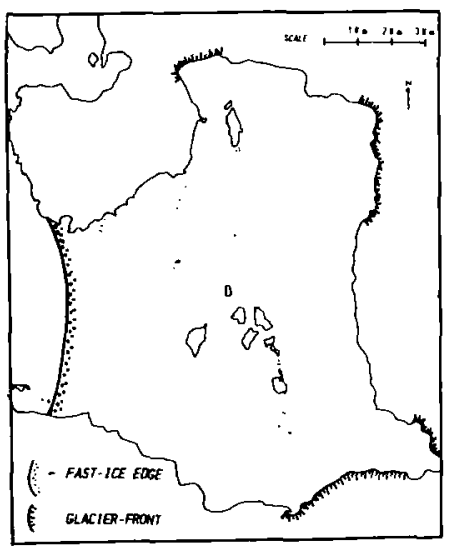

A

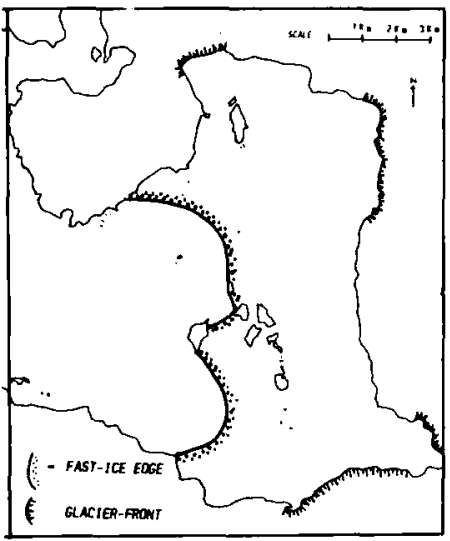

B

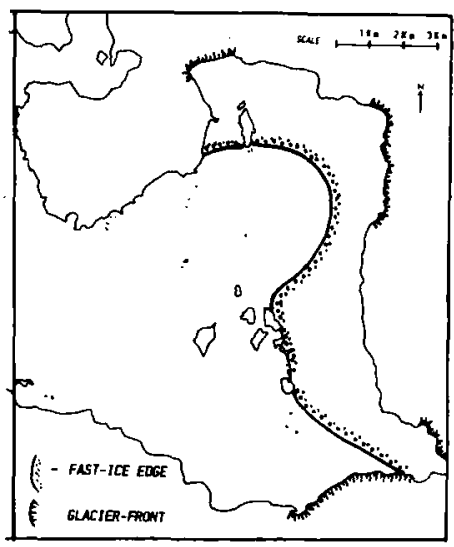

C

Fig. 4. Three successive stages of the fast-ice cover in Kongsfjorden 1984. A: 15 March; B: 10 April; C: 19 April.

location of breathing holes were also noted. In addition, any signs of predator activity were noted, as were observations of the digging site and predator success (whether a seal had been killed or not) if the lair had been opened by predators. The precise location of each lair was determined by a laser rangefinder.

The linear dimensions were used to draw each lair on graph paper in a reduced scale. From this the sizes of tiggak and birth lairs were calculated. Areas in birth lairs obviously excavated by the pup were excluded. The distances between lairs were calculated by plotting each lair on a map of the study area and measuring the distances between them.

\section{Results}

Only areas to the lee and windward sides of hummocks or along pressure ridges had sufficient snow for lair construction. A total of 90 lairs were found and excavated. Twenty-eight of these were classified as birth lairs and 22 as tiggak lairs (Table
1). The first birth lair was recorded on March 24th. Table 1 shows that snow depths covering lairs varied between $45 \mathrm{~cm}$ and $145 \mathrm{~cm}$. The maximum height inside the lairs varied between $10 \mathrm{~cm}$ and $60 \mathrm{~cm}$. Table 1 shows that the means of maximum heights inside birth and tiggak lairs were of the same order of magnitude. The mean snow depth covering the lairs for birth lairs was $89 \pm$ S.D. $15 \mathrm{~cm}$ and for tiggak lairs $75 \pm$ S.D. $16 \mathrm{~cm}$. A Mann-Whitney U-test showed that this difference was significant $(p<0.0113)$.

The mean areas of birth and tiggak lairs are shown in Table 2. Birth lairs were significantly larger than tiggak lairs $(p<0.0012)$.

Fig. 5 shows the sites of all recorded lairs. Lairrich areas coincide with areas hatched in Fig. 3 as favourable for lair construction. The figure shows one birth lair isolated in the northwestern part of inner Kongsfjorden. With the exception of a few small pressure ridges this area of the fjord consisted mainly of flat ice with about $15 \mathrm{~cm}$ snow cover. The distance from this birth lair to the nearest other lair was about $5000 \mathrm{~m}$. Only breathing holes could be found in between.

Table 1. Mcasurements from different types of subnivean lairs.

\begin{tabular}{llllll}
\hline Classification & No. & $\begin{array}{l}\text { Mean max. height } \\
\text { of lair }(\mathrm{cm})\end{array}$ & $\begin{array}{l}\text { Range } \\
(\mathrm{cm})\end{array}$ & $\begin{array}{l}\text { Mean snow depth } \\
(\mathrm{cm})\end{array}$ & $\begin{array}{l}\text { Range } \\
(\mathrm{cm})\end{array}$ \\
\hline Birth lairs & 28 & $31 \pm$ S.D.6 & $15-40$ & $89 \pm$ S.D.15 & $65-130$ \\
Tiggak lairs & 22 & $30 \pm$ S.D.11 & $10-60$ & $75 \pm$ S.D.16 & $45-100$ \\
Indet. lairs & 40 & $31 \pm$ S.D.7 & $20-60$ & $91 \pm$ S.D.24 & $55-145$ \\
Total & 90 & $31 \pm$ S.D.9 & $10-60$ & $87 \pm$ S.D.20 & $45-145$ \\
\hline
\end{tabular}


Table 2. Sizes of birth- and tiggak lairs.

\begin{tabular}{lll}
\hline Type of lair & Mean size $\left(\mathrm{m}^{2}\right)$ & Rangc $\left(\mathrm{m}^{2}\right)$ \\
\hline Birth lair & $4.3 \pm$ S.D. 2.6 & $1.2-13.3$ \\
Tiggak lair & $2.4 \pm$ S.D.1.4 & $0.8-5.5$ \\
\hline
\end{tabular}

Lairs of the same type situated in the same snowdrift or within a $200 \mathrm{~m}$ radius were considered as belonging to the same complex, i.e. inhabited by the same animal. This gives a total of 24 birth lair complexes and 20 tiggak lair complexes discovered in the study area.

The distances from one birth lair complex to the nearest other birth lair complex, from one birth lair complex to the nearest tiggak lair complex, and from one tiggak lair complex to the nearest other tiggak lair complex are shown in Table 3. These distances were all of the same order of magnitude.
Table 3. Mean distances from one birth/tiggak lair complex to the nearest situated birth/tiggak Jair complex.

\begin{tabular}{lll}
\hline $\begin{array}{l}\text { Mean distance } \\
(\mathrm{m}) \text { to/from }\end{array}$ & Birth lair & Tiggak lair \\
\hline Birth lair & $513 \pm$ S.D.336 & $512 \pm$ S.D. 328 \\
Tiggak lair & $512 \pm$ S.D.328 & $598 \pm$ S.D.252 \\
\hline
\end{tabular}

Lairs attacked by arctic foxes and polar bears are listed in Table 4. Lairs attacked by arctic foxes had from 1 to 6 entry holes made by foxes. These holes seemed to be randomly distributed in relation to the lair's breathing hole. A total number of 19 lairs with signs of fox attacks were found. In six of these there was evidence of seals having been killed $(32 \%)$. Thirteen attacks by foxes on birth lairs were recorded, and in five cases the pup had been killed. This could be shown by the presence of lanugo and/or claw remains. Six attacks on indet. lairs were recorded, with indi-

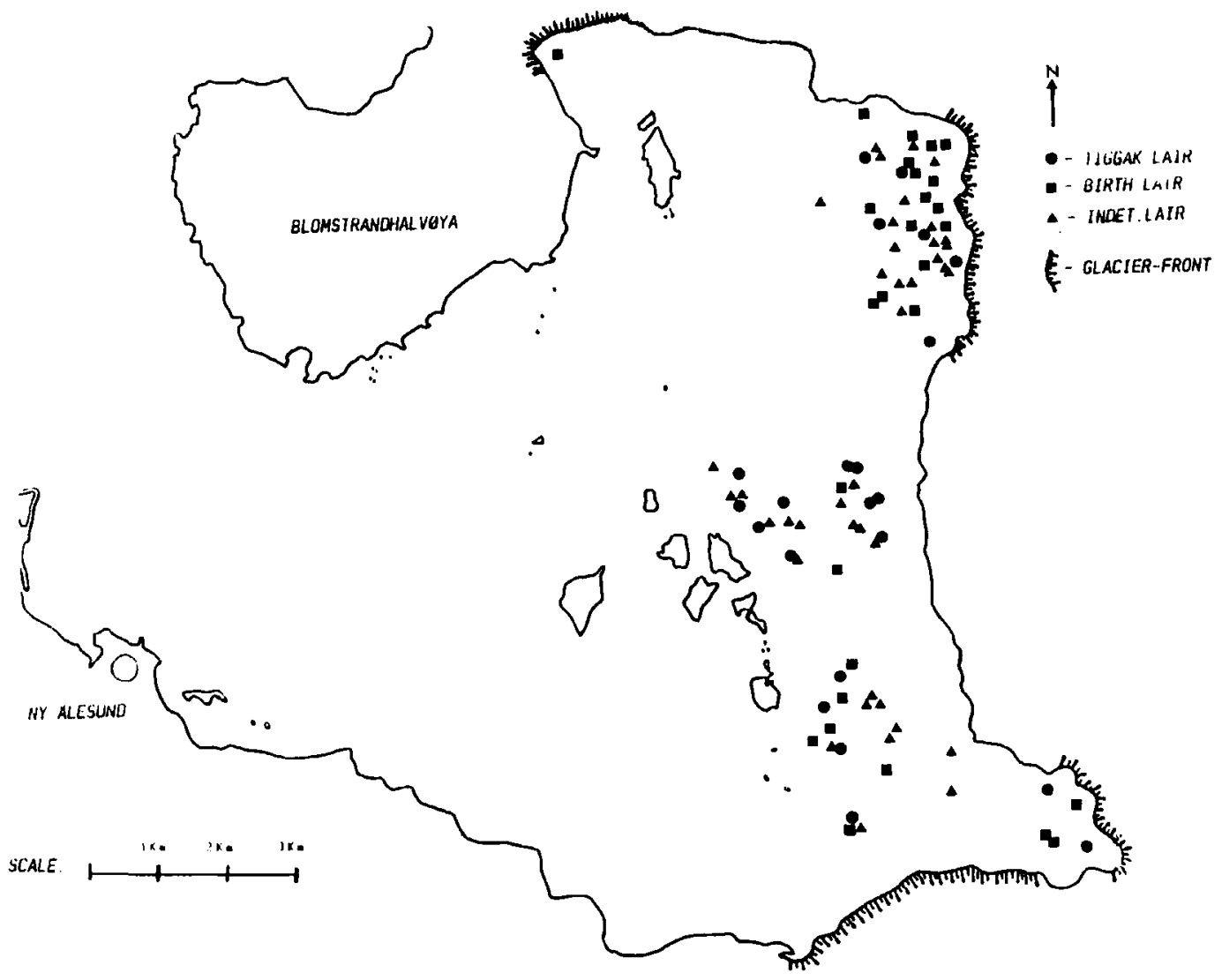

Fig. 5. Map showing the inner part of Kongsfjorden with the exact positions of the different lairs. 
Table 4. Arctic fox and polar bear hunting success on different types of ringed seal lairs.

\begin{tabular}{|c|c|c|c|c|c|c|}
\hline \multirow[b]{2}{*}{ Predated by } & \multicolumn{2}{|c|}{ Birth lair $(\mathrm{N}=28)$} & \multicolumn{2}{|c|}{ Tiggak lair $(N=22)$} & \multicolumn{2}{|c|}{ indet. lair $(N=40)$} \\
\hline & No. attacked & No. killed & No. attacked & No. killed & No. attacked & No. killed \\
\hline Arctic fox & 13 & 5 & 0 & 0 & 6 & 1 \\
\hline Polar bear & 4 & 1 & 2 & 0 & 7 & 0 \\
\hline Total & $16^{*}$ & 6 & 2 & 0 & 13 & 1 \\
\hline
\end{tabular}

* One lair attacked by both fox and bear.

cations in one case that a kill had taken place. No remains were present to indicate whether the seal killed was a whitecoat or an older animal. Taking into consideration the difference in size between an arctic fox and an adult ringed seal, it is most likely that the killed seal was a whitecoat. No fox attacks on tiggak lairs were registered.

Tracks indicated that foxes had systematically searched areas with sufficient snow for ringed seal lairs. The foxes had often marked a lair with urine or faeces or both, without digging into it. In lairs attacked by foxes, urine or faeces was usually found either on top of the lair or inside.

Lairs attacked by polar bears had from one to three digging sites, often located close to the breathing hole. Polar bears had entered 13 lairs. In one of these ( $8 \%$ ), a birth lair, a whitecoat had been killed. Two polar bear attacks on tiggak lairs were recorded. The polar bear tracks indicated that this animal had also systematically searched areas suited for ringed seal lairs. Arctic fox tracks were frequently found following the bear tracks. This suggests that the arctic fox may be scavenging the remains of seals struck by polar bears. One birth lair had apparently been attacked by both arctic fox and polar bear, although there were no signs of a successful hunt. Obviously in this case the arctic fox had made the first attack, as it could otherwise have entered the lair through the holes made by the polar bear.

\section{Discussion}

The purpose of this study was to record and excavate all seal lairs in the inner part of Kongsfjorden in 1984. A total of 90 lairs were recorded, but the area had probably contained more. Taugbøl (1982) found 193 lairs in Kongsfjorden in 1979. However, the ice conditions in 1979 were quite unusual with land-fast ice stretching to the outer parts of the fjord.
The dogs tended to lose interest in the search when they were worked too long. In addition, unfavourable wind conditions may have caused the dogs to overlook lairs. Although the favourable areas were also searched with probes, it is obvious that some lairs may have been missed. Lairs which had been attacked by predators and later on covered by snow, had less chance of being discovered because the dogs were rarely interested in them: these were often found by using the probes. In addition, favourable lairsites on the fjord ice in the southeastern parts of Kongsfjorden disappeared before they could be searched.

The consequences of the early disappearance of fjord ice with possible birth lairs can only be surmised: (1) The pups may have taken to water and sought refuge on the remaining fast ice, without the protection offered by a lair. The mortality of such pups will probably increase due to a higher risk of predation and exposure. (2) The mother and pup may follow the drifting ice and remain sheltered. However, the lactation period may be shortened by unstable ice conditions leading to the early separation of mother and pup. (3) Mother and pup may become parted when the fast ice breaks up. The pup will then have to manage on its own or die. When left alone the pup may suffer from malnutrition and starvation, and become a so-called starveling. McLaren (1958) assumes that starvelings are pups separated from their mothers before weaning because the birth lair ice is separated from the fast ice sheet.

In this study two types of lairs are distinguished: tiggak lairs and birth lairs. Classification of lairs other than those proved to be difficult, and they were all recorded as indetermined (indet.) lairs.

Twenty-eight of the 90 lairs found were classified as birth lairs. However, this is probably an underestimate because several haul-out lairs classified as indetermined probably would have evolved into birth lairs, but were excavated before 
the pup was born. This was indicated by the fact that more birth lairs relative to indetermined lairs were found as the pupping season progressed.

The snowcover over birth lairs was significantly deeper than over tiggak lairs. Deeper snow means for one thing that a predator needs longer time to penetrate the lair. The question then arises whether the ringed seals can predict where the deepest snow will be found. Areas to the leeand windward sides of the largest hummocks and icebergs frozen into the fast ice tend to have the deepest snow. These icebergs have the deepest penetration into the water. It is possible that ringed seals are aware of this fact, and that the females make their birth lairs over breathing holes in such areas. McLaren (1958) suggests that seals make an active choice or prediction of suitable snow depths.

The maximum height inside lairs varied between $10 \mathrm{~cm}$ and $60 \mathrm{~cm}$. Low heights probably result from settling of the lair roof caused by warm weather. Lair heights of $60 \mathrm{~cm}$ probably correspond to the maximum reach of an adult ringed seal lying on its side and scratching the snow with its foreflipper (Smith \& Stirling 1975). A comparison of the inside of tiggak and birth lairs showed that they were about the same height. Lydersen (1984) showed that ringed seal males and females in the Kongsfjorden area reach the same size and we therefore assume that they have the same reach when digging lairs.

No information on the area of ringed seal lairs is available from the literature. An areal comparison of birth lairs and tiggak lairs from Kongsfjorden showed that birth lairs were significantly larger. The difference in size may be due to the need of pregnant ringed seals for more space when giving birth, whereas the male only uses its lair for hauling out.

No information on the size of ringed seal territories has been found in the literature. However, territorial aggression has been recorded for ringed seals of both sexes during the breeding period (Stirling 1977). The size of the territories depends on lair facilities. When there are increased possibilities for lairs which enable the female to dig out the necessary number of lairs for its birth lair complex within a small area, the territories will probably be smaller than when circumstances are less favourable. The distances measured between the lair complexes in Kongsfjorden (Table 3) give an indication of the size of ringed seal territories in the area in the spring of 1984.
The first birth lair was recorded on March 24th. This corresponds to the usual start of the pupping season in other Arctic areas (Chapskii 1940; Smith 1973; Smith \& Stirling 1975). Chapskii (1940) refers to Kotgoff who claims that ringed seals in the Spitsbergen area pup at the end of June. No further information about this contention has been available, however, and it does not apply to ringed seals in the Kongsfjorden area.

Smith (1976) studied the arctic fox as a predator of ringed seals in lairs over three years and estimated that foxes manage on average to kill a pup in $26.1 \%$ of its attempts. His study area supports one of the densest populations of arctic foxes in the North American arctic. In Kongsfjorden the corresponding hunting success was calculated to be $32 \%$. This figure, however, is based on relatively few observations. Smith's figure comprised records of 113 ringed seal lairs attacked by foxes, $53.1 \%$ of which were classified as birth lairs, $40.7 \%$ as haul-out lairs, and $6.2 \%$ as tiggak lairs. Smith suggests that the fox is unable to distinguish between birth lairs and other lairs with the possible exception of tiggak lairs. This corresponds well with the observations from Kongsfjorden where no fox attack on tiggak lairs was noted.

Lairs marked but not attacked by the fox were often observed. It is possible that the fox senses the lair is empty and marks it so as to be able to find it more easily later on, or to keep other foxes away. The fox's site of attack did not seem to be centred on the breathing hole. We might assume that the most effective way of trapping a pup was to dig down to the breathing hole, thus preventing the pup from escaping. Since this is not the case, it would seem that the fox may have difficulties in sensing the location of the breathing hole when attacking a lair.

Polar bears, however, often attacked the lair close to the breathing hole. This may be by chance, but should prove to be the most effective site of attack. A bear kills both adults and pups, so the size of the seal it corners in the lair does not matter. Of the 13 lairs attacked by polar bears only one showed proof of a kill (7.7\%). Stirling \& Archibald (1977) found that the success rate of polar bears hunting seals at subnivean breathing holes and birth lairs varied between $6.4 \%$ and $8.6 \%$. These figures were calculated from 848 bear attack attempts on lairs investigated 19711975.

Two polar bears attacks on tiggak lairs were recorded in this study. Smith (1980) found that 
only $3 \%$ of the lairs attacked by bears were tiggak lairs. In his opinion there is strong evidence that polar bears purposely avoid digging into these lairs. He observed nine cases of bear tracks close enough for the tiggak lairs to be detected by the bear without any attempt to attack. He also mentions that Inuits in many areas do not like to eat the meat of tiggak seals, and, similarly, that sled dogs apparently do not eat such meat. We could often smell a tiggak lair several metres off. It would thus seem obvious that polar bears are able to distinguish between tiggak lairs and other types of lairs.

Smith (1976) suggests that the single most important source of natural mortality in the first year of life of ringed seals born in nearshore sea ice is fox predation. The studies in Kongsfjorden seem to support his statement. Mortality in ringed seal pups caused by sources other than predation is difficult to assess. Smith (1976) found one dead pup in 119 birth lairs. No dead pups were found in the lairs excavated in Kongsfjorden.

Although scanty, the present material from Kongsfjorden gives some indications as to the distribution, abundance, and structures of subnivean ringed seal lairs. It also provides some knowledge of the degree of predation by polar bears and arctic foxes in this area during the spring.

Acknowledgements. - Wc thank the Norwegian Polar Research Institute and the Norwegian Ministry of the Environment for their joint funding of this project. Special thanks are given to the staff at $\mathrm{Ny}$ - $\AA$ lesund and the Governor's office for help given to us during our stay in Svalbard. We are especially grateful to Svein Bergerud for the use of his dog 'Rabben'.

\section{References}

Chapskii, K. K. 1940: The ringed seal of western seas of the Soviet Arctic. (The morphological characteristics, biology and hunting production.) Transl. Ser. Fish. Res. Bd Can. $1665,1971.147 \mathrm{pp}$.

Gjertz, I. \& Lydersen, C. 1983: Ringed seal Phoca hispida pupping in the Svalbard area. Fauna $36,65-66$ (in Norwegian).

Lydersen, C. 1984: Studies of age and population dynamic parameters of the ringed seal (Phoca hispida Schreber 1775) in the Sualbard area. Cand. real. thesis. Inst. mar. biol., avd. A., Univ. Oslo. 101 pp. (in Norwegian).

Lønø, O. 1970: The polar bear (Ursus maritimus Phipps) in the Svalbard area. Norsk Polarinst. Skr. 149.103 pp.

McLaren, 1. A. 1958. The biology of the ringed seal (Phoca hispida Schreber) in the eastern Canadian Arctic. Bull. Fish. Res. Bd Can. 118. 97 pp.

Smith, T. G. 1973: Population dynamics of the ringed seal in the Canadian eastern Arctic. Bull. Fish. Res. Bd Can. 181. $55 \mathrm{pp}$.

Smith, T. G. 1976: Predation of ringed seal pups (Phoca hispida) by the arctic fox (Alopex lagopus). Can. J. Zool. 54, 16101616.

Smith. T. G. 1980: Polar bear predation of ringed and bearded seals in the land-fast sea ice habitat. Can. J. Zool. 58, 22012209.

Smith, T. G. \& Hammill, M. O. 1981: Ecology of the ringed seal, Phoca hispida, in its fast ice breeding habitat. Can. J. Zool. 59, 966-981.

Smith, T. G. \& Stirling, I. 1975: The breeding habitat of the ringed seal (Phoca hispida). The birth lair and associated structures. Can. J. Zool. 53, 1297-1305.

Stirling, I. 1974: Mid-summer observations on the behavior of wild polar bears (Ursus maritimus). Can. J. Zool. 52, 11911198.

Stirling, I. 1977: Adaptations of Weddell and ringed seals to exploit the polar fast ice habitat in the absence or presence of surface predators. Pp. 741-748 in Llano, G. A. (ed.): Adaptations within Antarctic Ecosystems. Proceedings of the Third SCAR Symposium on Antarctic biology. The Smithsonian Institution, Washington D.C., 1252 pp.

Stirling. I. \& Archibald, W. R. 1977: Aspects of predation of seals by polar bears. J. Fish. Res. Bd Can. 34, 1126-1129.

Stirling, I. \& Calvert, W. 1979: Ringed seal. FAO Fish. Ser $5(2), 66-69$.

Stirling, I. \& Latour, P. B. 1978: Comparative hunting abilities of polar bear cubs of different ages. Can. J. Zool. 56, 17681772.

Taugbøl, G. 1982: Thermoregulation, energy balance and development of ringed seal pups in their first weeks of life. Cand. real. thesis, Zoofys. Inst. Univ. Oslo. 102 pp. (in Norwegian). 